\title{
Dual Banking System dimata kaum Milenial Bandung Jawa Barat antara Kebutuhan dan Kehalalan Produk
}

\author{
Arbian Jihari Ramasuna', Dadang Husen Sobana² \\ arbianjihariramasuna1999@gmail.com
}

Manajemen Keuangan Syariah, UIN Sunan Gunung Djati, Bandung, Indonesia

Manajemen Keuangan Syariah, UIN Sunan Gunung Djati, Bandung, Indonesia

KEYWORD ABSTRACT

Dual Bank System, Halal,

Keuangan Syariah, Milenial, Produk

\begin{abstract}
Sistem perbankan dual banking system menjadi sistem yang dianut di negara Indonesia. Asset dikelola supaya tidak terlalu banyak dana yang masih menganggur juga sebagai salah satu berdasarkan kebijakan dari sekian banyak manajemen untuk diprioritaskan baik bank konvensional juga bank syariah. Asal pendapatan terbesar yaitu dari dana pihak ketiga yang diperoleh bank syariah dan bank konvensional, dana tersebut berfungsi sebagai forum keuangan bank permanen yang dikelola sedemikian rupa dan mempunyai fungsi yaitu funding dan lending. Pada pembangunan ekonomi nasional dibutuhkan praktik hukum ekonomi syariah, melalui pusat ekonomi atau aneka macam forum yang berkecimpung dalam sektor riil, positifnya adalah pengaruh terhadap ekonomi nasional semakin berkembang dan bertumbuh. Produk halal mempunyai sertifikasi dan labelisasi untuk perspektif maslahat menaruh jaminan, pertumbuhan, berita mengenai mengkonsumsi produk halal yang dipakai masyarakat. Tunjangan profesi dan labelisasi terhadap kebutuhan konsumen yaitu mempunyai produk yang halal dikategorikan maslahat dharuriyyah lantaran mengakibatkan semakin rumitnya memilih produk halal atau haram karena terjadi beberapa faktor kemajuan pengetahuan dan teknologi, dan diharapkan untuk menetapankan labelisasi produk halal dan tunjangan profesi.
\end{abstract}




\section{Introduction}

Di dalam UU Nomor 10 Tahun 1998 dijelaskan tentang Perbankan di Indonesia menggunakan dua sistem yaitu perbankan syariah dan konvensional. Perbankan di Indonesia harus mempersiapkan berbagai peraturan dan juga fasilitas yang berfungsi menjadi penunjang yang bisa mendukung operasional bank syariah, karena Bank Indonesia menjadi pemegang otoritas dan hal tersebut telah diatur pada UU Nomor 23 Tahun 1999 mengenai Bank Indonesia.

Dual banking system memberlakukan 2 (dua) sistem yang tidak cocok, sistem tersebut menggunakan prinsip-prinsip dan aplikasi perbankan yang tidak cocok satu dengan lainnya. Sistem ini memberlakukan sistem aturan nasional dan sistem aturan syriah dengan menandai adanya suatu "dualisme" dalam sistem tersebut. Penerapan pada perbankan syariah yang ada di Indonesia tidak boleh bertentangan menggunakan aturan Islam secara normatif (Al-Qur'an, Sunnah/Hadits, dan ijtihad), dan juga tidak boleh bertentangan pada aturan positif yang berlaku pada Indonesia. Aturan tersebut ada pada sistem dualisme menurut Sutan Remy Sjadeni.

Dalam bidang perindustrian dan perdagangan nasional sudah memproduksi banyak sekali jenis barang atau jasa yg bisa dikonsumsi untuk membangun dan mengembangkan perekonomian di Indonesia. Kemajuan teknologi telekomunikasi dan informatika sudah memperluas ruang mobilitas arus transaksi barang dan atau jasa melintasi batas-batas daerah suatu negara untuk mendukung globalisasi dan perdagangan bebas, sebagai akibatnya produksi dalam negeri dan luar negeri mendapatkan barang dan jasa yang ditawarkan dari berbagai jenis.

\section{Metode}

Penelitian ini memakai metode survei dengan pendekatan kuantitatif. Meningkatkan sampel menurut suatu populasi dan memakai kuisioner menjadi pengumpulan data tersebut merupakan tujuan dari metode ini untuk mengangkat beberapa besar data. Dalam metode survei dilakukan penilaian dan perbedaan hal-hal yang sudah dilakukan masyarakat pada memegang keadaan maupun perkara yang sejenis dan produknya bisa dipakai pada penyusunan persiapan dan pengutipan kesimpulan pada masa yang mendatang. Analisis tersebut dikelola melalui Google Form menggunakan aneka macam pertanyaan kemudian disebarkan melalui Grup WhatsApp dilaksanakan dalam bulan Juli hingga bulan Agustus 2020.

Pengumpulan data utama yg dikutip pribadi berdasarkan asalnya, ditemukan berdasarkan narasumber pada Google Form. Data utama yg diharapkan contohnya data jenis kelamin, profesi, pendapatan, \& rekening bank diambil berdasarkan sebagian narasumber yang masih ada pada warga dibeberapa tempat 
Data sekunder didapatkan melalui penghimpunan laporan-laporan, dokumen, keterangan output kalkulasi dan semacamnya yang dipunyai melalui lembaga terkait. Data sekunder yg diperlukan contohnya data didapatkan berdasarkan Google Form pada penghitungan yg mempunyai rekening bank yg sudah teruji kebenarannya dan diperoleh berdasarkan instansi terkait yg bisa pada percaya keabsahannya.

Google Form kerap dipakai pada metode penelitian survei, adalah bentuk komunikasi secara daring, misalnya angket buat bisa menghimpun informasi. Cara Google Form tersebut menggunakan dasar kuisioner yang sudah dibikin. Data yang diperoleh menggunakan cara tersebut adalah mencakup ciri narasumber (jenis kelamin, profesi, pendapatan, rekening bank yg dipakai).

Analisis data memenuhi buat membalas pembahasan analisis yang sudah diakui lebih dahulu. Analisis data merupakan cara pemotongan data dan penyajian data menggunakan mengkategorikan pada suatu gambaran yang gampang dipahami atau dipraktikan.

\section{Result and Discussion}

Yang dimaksud dual banking system merupakan bahwa bank bisa menjalankan dua aktivitas sekalian, yaitu aktivitas perbankan yg berlandas bunga dan aktivitas perbankan yg berlandas nonbunga. Bank yang mengubah sistemnya memakai prinsip-prinsip syari'ah, maka semua prosedur kerjanya mengikuti prinsip-prinsip perbankan syari'ah. Sedangkan bank yg melakukan ke dua duanya sekaligus, maka diatur sedemikian rupa prosedur kerjanya, yang terpenting melibatkan hubungan terhadap aktivitas-aktivitas yg berlandas bunga yaitu karakteristik menurut perbankan konvensional menggunakan aktivitas yang bebas pembeda menurut perbankan syari'ah, sebagai akibatnya antara kedua belah pihak bisa dibagi. Pada bank yang mengelola secara konvensional, pendapatan bank yg primer asal menurut bunga yg dihitung dari dalam prosentase eksklusif menurut pinjaman, sedangkan dalam perbankan syari'ah pendapatan bank dihitung menurut bagi output yg dihitung secara proporsional menurut pinjaman atau kapital yg diberikan bank pada nasabah.

Eksistensi bank syariah pada Indonesia sebagai bagian menurut sistem perbankan nasional selama 23 tahun, menjadi cara lain menurut bank konvensional. Tumbuh kembang bank syariah pada Indonesia juga bukanlah hal yang singkat pada prosesnya. Perkembangan yang sangat pesat juga terjadi berdampingan menggunakan bank konvensional karena bank nasional diperlukan untuk mangalami masalah tersebut, menjadi resiko diresmikannya dual banking system.

Aplikasi sistem perbankan syariah pada wilayah negara dari output yang didapat dalam Konfenrensi Organisasi Islam (Organization Islamic Conference) dalam 1983 oleh Abdul Mumin menyebutkan beberapa contoh, disebutkan pada 4 (empat) kategori: Pertama, sistem tunggal (mono banking Fakultas Ekonomi dan Bisnis Islam - UIN Sunan Gunung Djati Bandung 
system); Kedua, sistem ganda (dual banking system); Ketiga, sistem konvensional modifikasi (conventional plus system), \& Keempat, sistem konvensional (conventional system).

Kata halal dari berdasarkan akar istilah yang artinya "lepas" atau "tidak terikat". Sesuatu yang terlepas berdasarkan ikatan bahaya duniawi dan ukhrawi adalah halal. Halal berarti boleh istilah tersebut ada dalam bahasa hukum. Sunnah, anjuran buat dilakukan, atau makruh (anjuran buat ditinggalkan), juga mubah (netral/ bolehboleh saja), kata tersebut meliputi segala sesuatu yang diperbolehkan agama.

Barang atau jasa yang terkandung menggunakan makanan, minuman, obat, kosmetik, produk kimiawi, produk kimiawi, produk biologi, produk rekayasa genetik, dan barang yang digunaan untuk dikonsumsi, dipakai atau digunakan oleh masyarakat merupakan definisi dari produk. Produk yang sudah dinyatakan sesuai menggunakan syariat Islam merupakan produk yang halal. Pengakuan kehalalan suatu produk yang diakui oleh badan penyelenggara agunan produk halal dari fatwa halal tertulis yang difatwakan majelis ulama merupakan sertifikat halal. Perindikasi kehalalan suatu produk merupakan labelisasi halal.

Latar belakang pada awal menyatakan bahwa populasi warga pada Bandung didominasi sang generasi milenial dan penggunaan rekening bank syariah yang relatif tinggi dan membuka peluang buat membentuk kebutuhan dan pasar yang akbar buat kebutuhan gaya hayati yang halal. Hal ini diperkuat sang analisis kuantitatif yang menampakan banyaknya manfaat menaruh prioritas krusial dalam gaya hayati halal pada mencapai syariat Islam. Terciptanya prioritas pada pendekatan kuantitatif bisa dijadikan acuan dasar buat memperbanyak terbentuknya halal lifestyle berbasis dual banking system. Dalam pembentukan analisis kuantitatif diharapkan jumlah prioritas yg sebagai poin krusial terbentuknya kekuatan.

\subsection{Penerapan Dual Banking System di Indonesia}

Pasar perbankan konvensional merupakan penerapan dual banking system yang terjadi di Indonesia untuk sistem menggunakan porsi yang paling besar. Jika dibandingkan menggunakan perbankan konvensional yang hanya mencapai 2,5\%, perkembangan sistem tersebut relatif tinggi. Penerapan dual banking system yang dilakukan dalam sistem perbankan nasional menimbulkan ketidak jelasan. Aktivitas commercial banking dan investment banking untuk aktivitas operasional bank syariah melalui kedua fungsi intermediasinya dibatasi bahkan dipisahkan. Subsidiary bank umum (commercial bank) \& forum keuangan nonbank merupakan kegiatan yang hanya dilakukan melalui investment banking. (Zainul Arifin, 2012) Dual banking system yang berada di Indonesia mempunyai tujuan yaitu, Ketika terjadinya krisis keuangan lantaran secara paralel memiliki interaksi keuangan terbatas satu sama lain dengan membentuk diversifikasi risiko yang bisa mengurangi Fakultas Ekonomi dan Bisnis Islam - UIN Sunan Gunung Djati Bandung 
perkara systemic risk. Upaya restrukturisasi perbankan adalah pemberlakuan sistem tersebut. Karenanya perbankan yang bertenaga mengindikasikan bertenaga atau turunya perekonomian suatu negara.( Chatu Mongol Sonakul, 2000)

Menjadi dasar aturan primer bagi pendirian \& aktivitas bank syariah merupakan pemberlakuan dual banking system bagi bank syariah pada Indonesia melalui UU Perbankan Syariah, bank syariah atau bank generik syariah sebagai anak perusahaan bank generik konvensional lebih diartikan menjadi konversi bank konvensional, atau Islamic Window atau Unit Usaha Syariah yang juga bank konvensional.

Pengembangan sistem perbankan di Indonesia dengan dual banking system atau sistem perbankan ganda. Sistem ini dibuat sebagai aternatif dalam dunia perbankan. Pada dasarnya sistem kerja bank Islam sama dengan bank konvensional. Hanya saja cara kerja bank Islam adalah berdasar prinsip syariah. Ada banyak perbedaan yang ditawarkan bank Islam seperti produkproduknya, sistem operasi yang menggunakan prinsip profit loss sharing, dan lain-lain.

\subsection{Layanan Perbankan Dual Banking System Pada Generasi Millenial Bandung}

Generasi milenial yang ada di Bandung menuntut segala sesuatu yang sanggup dilakukan menggunakan cara yang cepat, mudah namun halal berdasarkan syariat Islam karena perkembangan teknologi di wilayah tersebut sangat pesat. Industri perbankan menjawab kebutuhan tadi menggunakan meluncurkan layanan dual banking system.

Untuk menyediakan cara lain jasa perbankan yang semakin lengkap untuk warga Indonesia maka pengembangan sistem perbankan syariah di Indonesia dilakukan pada kerangka dual-banking system atau sistem perbankan ganda pada kerangka Arsitektur Perbankan Indonesia (API). Mobilisasi dana warga secara lebih luas untuk mempertinggi kemampuan pembiayaan bagi sektorsektor perekonomian nasional maka sistem perbankan syariah dan perbankan konvensional secara sinergis mendukung keputusan tersebut.

Generasi milenial yang terdapat di Bandung menggunakan karakteristik sistem perbankan syariah yang mengelola prinsip output menaruh cara lain sistem perbankan yang sama-sama bermanfaat, investasi yang berakhlak, menunjukkan aspek keadilan pada bertransaksi, menyingkirkan aktivitas untung-untungan pada bertransaksi keuangan, dan meneguhkan nilai-nilai kebersamaan dan solidaritas pada produksi. Perbankan syariah menggunakan sistem yang bijak dan bisa disukai oleh semua golongan warga Indonesia yaitu dengan mempersiapkan produk dan layanan jasa perbankan yang majemuk menggunakan skema keuangan yang lebih bervariasi.

Menggabungkan interaksi antara sektor keuangan menggunakan sektor riil dan membangun harmonisasi di antara ke dua sektor tersebut dengan cara meluasnya penggunaan aneka macam Fakultas Ekonomi dan Bisnis Islam - UIN Sunan Gunung Djati Bandung 
produk dan instrumen keuangan syariah, dalam konteks tersebut masuk dalam pengelolaan perekonomian makro. Aktivitas keuangan dan usaha warga akan mengurangi transaksi-transaksi yang bersifat abstrak jika semakin meluasnya penggunaan produk dan instrumen syariah yang mendukung, sebagai akibatnya akan menaruh donasi yang signifikan terhadap pencapaian kestabilan harga jangka menengah sampai panjang dengan mendukung stabilitas sistem keuangan secara keseluruhan.

Pengembangan industri perbankan syariah nasional semakin mempunyai landasan aturan yang baik dan mendorong pertumbuhan secara lebih cepat lagi tertera pada UU No.21 Tahun 2008 mengenai Perbankan Syariah yang terbit lepas 16 Juli 2008. Dibutuhkan langkah industri perbankan syariah untuk mendukung perekonomian nasional akan semakin signifikan, maka dengan adanya kemajuan perkembangannya yang bagus kemudian mendekati homogen-homogen pertumbuhan aset lebih berdasarkan $65 \%$ pertahun pada 5 tahun terakhir.

\subsection{Ekosistem Halal di Bandung Dorong Perkembangan Ekonomi Syariah}

Kinerja keuangan syariah pada daerah ini diperhitungkan akan semakin meningkat karena terciptanya sistem ekonomi halal di Bandung. Apabila, peminat generasi milenial buat memakai layanan keuangan syariah terus berkembang.

Perbankan syariah hadir bukan menjadi pesaing dari perbankan konvensional untuk itu masyarakat mengerti hal tersebut. Masyarakat memahami keberadaan forum keuangan untuk mewujudkan kebutuhan produk keuangan syariah. Saat ini perbankan syariah menggunakan perbankan konvensional sanggup berjalan berdampingan saling membantu karena kondisi itu tidak sesuai apabila dibandingkan tahun-tahun sebelumnya.

Spesifik di daerah Bandung menilai perkembangan akan lebih baik lantaran didukung potensi ekosistem halal yang terdapat sehinnga berdampak positif bagi jasa keuangan syariah. Serta generasi milenial yang terdapat di Bandung semakin bebas menggunakan menggunakan fasilitas keuangan syariah.

Halal food, halal tourism, dan halal fashion merupakan potensi untuk mendorong ekosistem halal yang ada di Bandung. Di Bandung pertumbuhan ekonomi syariah akan lebih baik lagi. Pengenalan dan pembelajaran tentang keuangan syariah akan semakin terus-mereus dilakukan oleh pelaku bisnis dan nasabah. Keputusan tadi dibutuhkan buat menaikkan pencerahan dan pemahaman rakyat.

Gaya hidup perilaku yang nampak dari aktivitas seseorang. Gaya hidup adalah pola hidup seseorang di dunia yang diekspresikan dalam aktifitas (activity), minat (interest) dan opininya (opinion). Gaya hidup itu sendiri menggambarkan "keseluruhan diri seseorang” dalam berinteraksi Fakultas Ekonomi dan Bisnis Islam - UIN Sunan Gunung Djati Bandung 
dengan lingkungannya. Gaya hidup akan berpengaruh terhadap perilaku konsumen dalam membelanjakan dan mengalokasikan waktu dan uang yang dimiliki, dimana hal tersebut ditentukan dari faktor eksternal dan faktor internal konsumen.

\subsection{Sertifikasi dan Labelisasi halal Perspektif Maslahat}

Output pemikiran aturan Islam yang semuanya dibangun atas pertimbangan maslahat merupakan bagian dari sertifikasi dan labelisasi produk halal. Kemaslahatan manusia merupakan misi yang dibawa oleh kepercayaan Islam sendiri. Tidak sanggup dilepaskan berdasarkan pertimbangan maslahat atau tidak begitu juga ketentuan-ketentuan hukumnya. Demikian juga, dari masa ke masa selalu mengalami perubahan dan perkembangan seiring dinamika yang terjadi pada tengah masyarakat tentang “kemaslahatan". Tenang dan tentram arti dari al-ishlah yang bermakna maslahat. Damai berorientasi dalam fisik sedangkan tentram berorientasi dalam psikis.

Mafsadat berdasarkan fasada yafsudu adalah sesuatu yang mengganggu dan kurang baik merupakan arti dari maslahah. Konsep maslahat identik menggunakan manfaat didalam perspektif Islam. Semua hal yang berisi manfaat berdasarkan usaha mendapatkanya juga menyingkirannya berdasarkan resiko. Menjaga kepercayaan, jiwa, akal, keturunan dan harta benda merupakan manfaat dari maslahat sebagai tujuan Allah SWT kepada hambanya. Suatu dasar yang berhubungan dengan kebaikan pada kehidupan manusia merupakan manfaat. Manfaat yang sinkron fitrah manusia, lantaran Islam merupakan kepercayaan yg sinkron menggunakan fitrah demikian juga menggunakan aturan-aturan yg terkait dengannya merupakan manfaat dan maslahat yang terdapat pada aturan Islam.

Pekerjaan yang membuat sesuatu yang baik biarpun hasinya kurang secara eksklusif maka termasuk kategori amal saleh karena maslahat sanggup dijadikan dalil, impak maslahat dan mafsadah tidak hanya pada dunia, akan tetapi pula berpengaruh dalam kehidupan akhirat. Output yang benar pada era kini dan yang akan tiba berakibat untuk setiap pekerjaan yang dipercaya merupaka maslahat. Maslahat tidak dievaluasi berdasarkan kepuasan substansi belaka, namun semua sebagai keinginan untuk fisik, jiwa \& roh manusia. Wajib didahulukan yaitu maslahat kepercayaan sebagai dasar bagi maslahat yg lain, \& posisinya. (Ika Yunia Fausia dan Abdul Kadir, 2015)

Maslahat didefinisikan menjadi fungsi atau aktivitas yang berisi manfaat. Mengambil manfaat dan menolak kemudharatan pada rangka memenuhi tujuan-tujuan syariat merupakan pendapat dari Imam al-Gazali. Memutuskan aturan dari dalil-dalil yang masih ada dalam nash merupakan maslahat dikemukakan ulama ushul fikh pada membahas metode yang dipergunakan waktu melakukan istinbat.

Fakultas Ekonomi dan Bisnis Islam - UIN Sunan Gunung Djati Bandung 
Kedudukan sertifikasi halal dalam sistem hukum Nasional di Indonesia mempunyai kedudukan yang sentral, karena sertifikasi halal termaktub dalam Undang-Undang Nomor 33 Tahun 2014 tentang Jaminan Produk Halal yang secara sistem hukum merupakan bagian dari sistem hukum, yaitu substansi hukum yang mempunyai kekuatan hukum dan kepastian hukum serata bersifat imperatif. Dan hal ini sebagai upaya perlindungan konsumen dalam hukum Islam. Fatwa halal yang dihasilkan oleh MUI ditaati dan dipatuhi oleh pemerintah dan umat Islam. Pemerintah mematuhinya seperti tercermin dalam peraturan perundang-undangan yang ada. Ketaatan pemerintah terhadap fatwa halal MUI terlihat dalam peraturan perundangundangan yang berlaku dan kebijakankebijakan yang dibuat pemerintah berkaitan dengan persoalan kehalalan pangan. Hal ini tercermin dalam UndangUndang Nomor 36 Tahun 2009 tentang Kesehatan, Undang-Undang Nomor 18 Tahun 2012 tentang Pangan, Undang-Undang Nomor 8 Tahun 1999 tentang Perlindungan Konsumen dan terakhir Undang-Undang Nomor 33 Tahun 2014 tentang Jaminan Produk Halal

$$
f(x)=a_{0}+\sum_{n=1}^{\infty}\left(a_{n} \cos \frac{n \pi x}{L}+b_{n} \sin \frac{n \pi x}{L}\right)
$$

Karakteristik responden yang mengisi kuesioner meliputi mereka para Mahasiswa Muslim di Indonesia, baik laki-laki dan perempuan. Profesi responden didominasi oleh Mahasiswa, Pedagang, Guru/Dosen, dan Buruh. Peneliti juga berusaha mengetahui jenis rekening bank yang dimiliki mereka baik rekening yang berada di bank syariah, bank konvensional atau kedua jenis bank. Deskripsi responden terlihat pada gambar-gambar sebagai berikut:

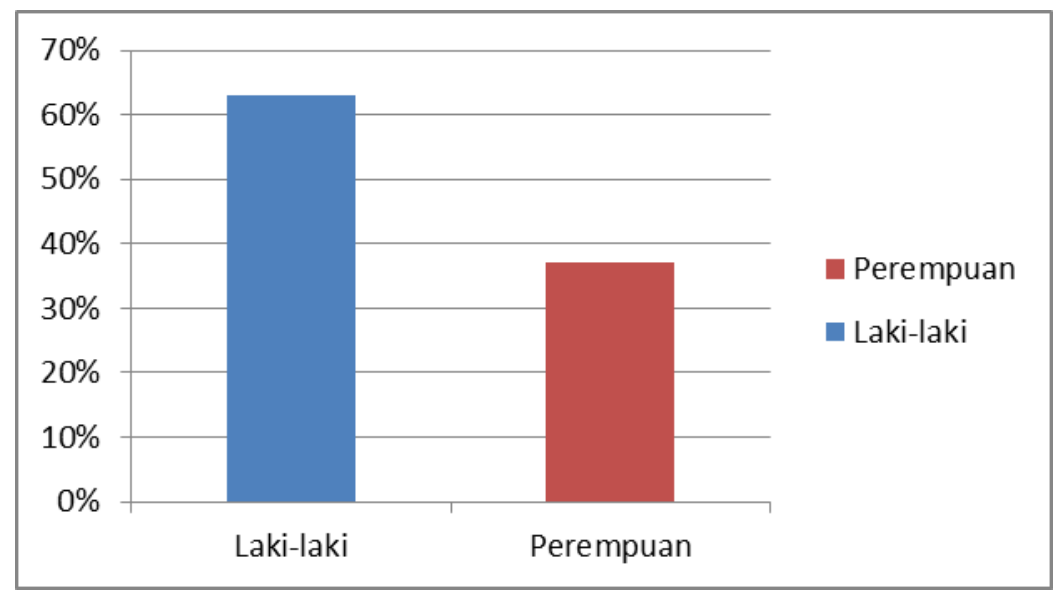

Deskripsi Responden Berdasarkan Jenis Kelamin

Berdasarkan gambar 1 jenis kelamin responden didominasi oleh responden yang berjenis kelamin laki-laki sebesar 63 \% dan laki-laki sebesar 37 \%. Jumlah responden laki-laki secara statistik lebih banyak dibandingkan perempuan. 


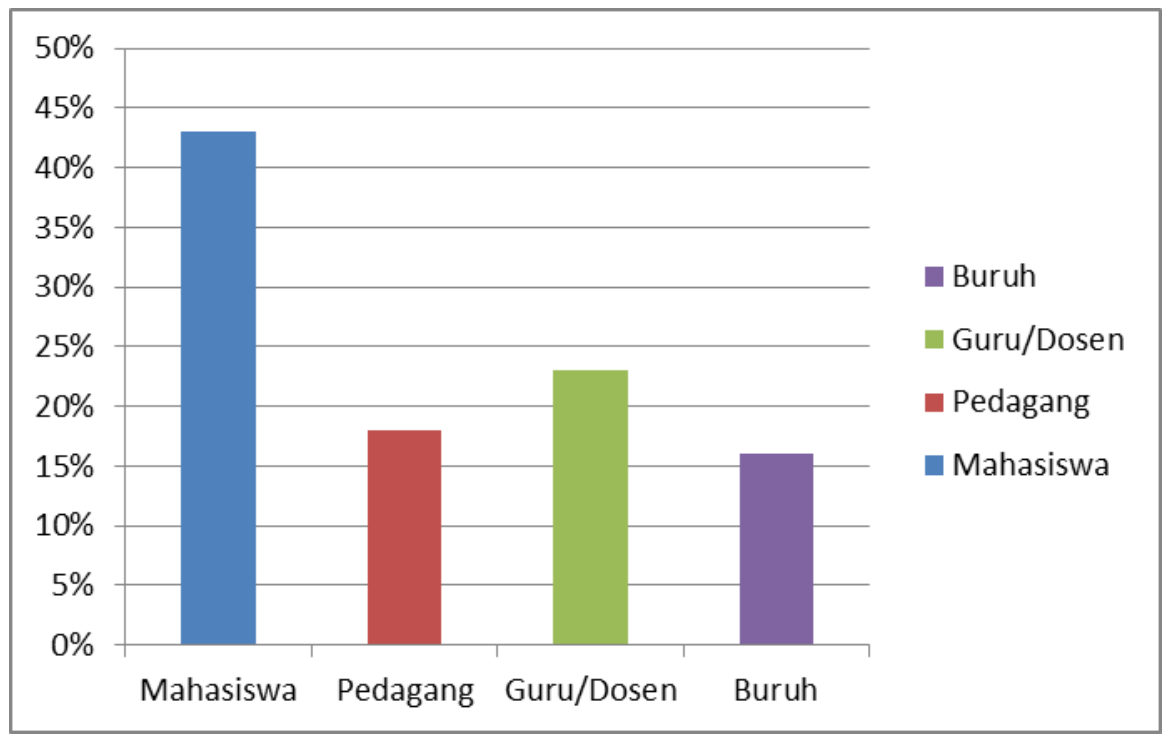

Deskripsi Responden Berdasarkan Profesi

Berdasarkan gambar 2 di atas pekerjaan responden didominasi oleh Mahasiswa sebesar $43 \%$, selanjutnya Pegadang sebesar $18 \%$, Guru/Dosen sebesar $23 \%$, terakhir profesi Buruh sebesar $16 \%$.

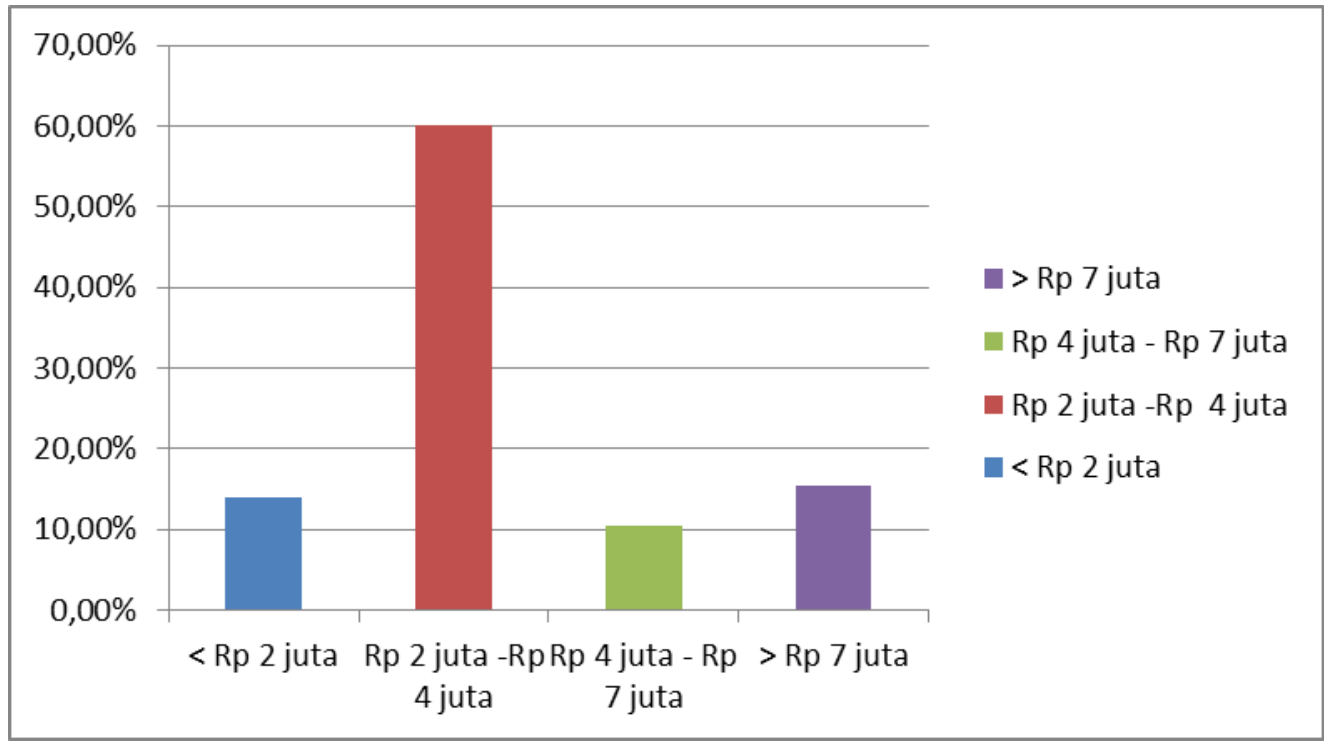

Deskripsi Resonden Berdasarkan Pendapatan

Berdasarkan gambar 3 di atas, berdasarkan pendapatannya peneliti membagi menjadi 4 kategori sebagai berikut: 1. Responden dengan pendapatan kurang dari Rp 2 juta sebesar 14,03\% 2 . Responden dengan pendapatan antara Rp 2 juta sampai dengan Rp 4 juta sebesar 60,06 \% 3 . Responden dengan pendapatan antara Rp 4 juta sampai dengan Rp 7 juta sebesar 10,50 \% 4 . Responden dengan pendapatan lebih dari Rp 7 juta sebesar 15,41\% Berdasarkan nominal pendapatan tersebut diketahui bahwa seluruh responden merupakan penduduk kalangan menengah Muslim. Responden yang mendominasi adalah responden dengan pendapatan antara Rp 2 juta sampai dengan Rp 4 juta (mid middle).

Fakultas Ekonomi dan Bisnis Islam - UIN Sunan Gunung Djati Bandung 


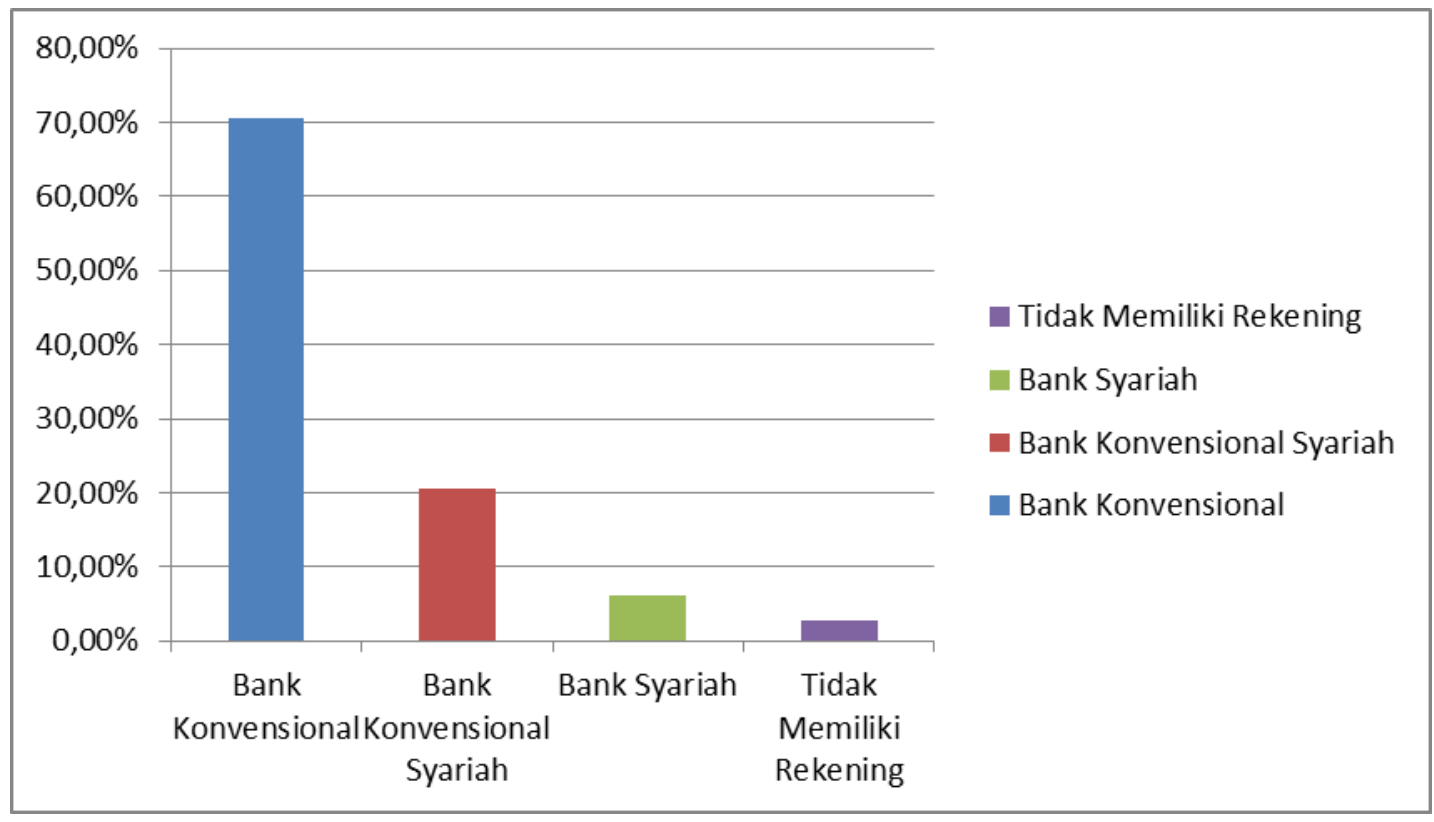

Deskripsi Responden yang Memiliki Rekening Bank

Berdasarkan gambar 4 di atas, rekening bank yang paling banyak dimiliki oleh responden adalah rekening bank konvensional saja sebesar 70,5\%, responden yang memiliki rekening bank konvensional dan juga bank syariah sebesar 20,6\%, responden yang hanya memiliki rekening bank syariah saja sebesar 6,2 \% dan responden yang tidak memiliki rekening bank sebesar 2,7 \%. Hasil pengisian kuesioner diperlihatkan pada Tabel 2 dan Tabel 3sSemua pernyataan dalam kuesioner yang dijadikan instrumen pengambilan data dalam penelitian ini telah dilakukan pengujian kesahihan (validitas) dan reliabilitas (konsistensi/keandalan). Semua pernyataan bersifat valid dan reliabel, artinya pernyataan-pernyataan dalam kuesioner adalah sahih dan dapat diandalkan. Total terdapat 20 pernyataan yang telah diisi oleh responden.

Tabel 2. Pendapat, Sikap dan Pandangan Kalangan Milenial Bandung Terhadap Dual Banking System

\begin{tabular}{|c|c|c|c|c|c|c|}
\hline \multirow[t]{2}{*}{ NO } & \multirow[t]{2}{*}{ Pendapat, Sikap, dan Pandangan } & \multicolumn{5}{|c|}{ Persentase $(\%)$} \\
\hline & & STS & $\mathrm{TS}$ & $\mathrm{N}$ & $\mathrm{S}$ & SS \\
\hline 1 & $\begin{array}{c}\text { Saya senang bank konvensional memiliki } \\
\text { anak usaha bank syariah/Unit usaha syariah } \\
\text { (UUS) }\end{array}$ & 2,8 & 2,5 & 27,8 & $\begin{array}{c}49,3 \\
7\end{array}$ & $\begin{array}{c}18,1 \\
2\end{array}$ \\
\hline 2 & $\begin{array}{c}\text { Saya percaya bank syariah/Unit Usaha } \\
\text { Syariah bisa beroperasi dalam bank } \\
\text { konvensional }\end{array}$ & $\begin{array}{c}1,8 \\
7\end{array}$ & 7,81 & $\begin{array}{c}29,0 \\
6\end{array}$ & $\begin{array}{c}54,0 \\
6\end{array}$ & 7,18 \\
\hline
\end{tabular}




\begin{tabular}{|c|c|c|c|c|c|c|}
\hline 3 & $\begin{array}{c}\text { Saya percaya anak usaha bank } \\
\text { Syariah/UUS dapat meningkat dengan } \\
\text { cepat bila tumbuh bersama bank induk } \\
\text { yang konvensional }\end{array}$ & $\begin{array}{c}2,1 \\
8\end{array}$ & 7,5 & $\begin{array}{c}39,0 \\
6\end{array}$ & $\begin{array}{c}42,8 \\
1\end{array}$ & 8,43 \\
\hline 4 & $\begin{array}{c}\text { Saya percaya Bank syariah/Unit Usaha } \\
\text { Syariah lebih cepat dikenal oleh } \\
\text { masyarakat jika digandeng oleh bank } \\
\text { konvensional }\end{array}$ & 2,5 & 7,5 & $\begin{array}{c}30,6 \\
2\end{array}$ & $\begin{array}{c}44,3 \\
7\end{array}$ & 15 \\
\hline 5 & $\begin{array}{c}\text { Saya percaya anak usaha Bank } \\
\text { Syariah/Unit Usaha Syariah kesulitan } \\
\text { berkembang jika memisahkan diri dari } \\
\text { bank induk konvensional }\end{array}$ & 5 & $\begin{array}{c}27,8 \\
1\end{array}$ & $\begin{array}{c}38,4 \\
3\end{array}$ & $\begin{array}{c}24,6 \\
8\end{array}$ & 4,06 \\
\hline 6 & $\begin{array}{c}\text { Sebaiknya setiap orang memiliki rekening } \\
\text { di bank syariah dan bank konvensional } \\
\text { sekaligus }\end{array}$ & 5 & $\begin{array}{c}23,4 \\
3\end{array}$ & $\begin{array}{c}44,6 \\
8\end{array}$ & $\begin{array}{c}21,2 \\
5\end{array}$ & 5,62 \\
\hline 7 & $\begin{array}{c}\text { Saya percaya lebih banyak untung daripada } \\
\text { rugi jika bank syariah/unit usaha syariah } \\
\text { tumbuh bersama bank induk yang } \\
\text { konvensional }\end{array}$ & 2,5 & $\begin{array}{c}10,3 \\
1\end{array}$ & $\begin{array}{c}50,9 \\
3\end{array}$ & $\begin{array}{c}31,8 \\
7\end{array}$ & 4,37 \\
\hline 8 & $\begin{array}{l}\text { Saya percaya bank syariah/anak usaha } \\
\text { syariah tidak bergantung sepenuhnya } \\
\text { dengan bank induk konvensional }\end{array}$ & $\begin{array}{c}1,5 \\
6\end{array}$ & 7,81 & $\begin{array}{c}37,8 \\
1\end{array}$ & $\begin{array}{c}46,2 \\
5\end{array}$ & 6,56 \\
\hline 9 & $\begin{array}{c}\text { Saya memilih menggunakan jasa bank } \\
\text { konvensional daripada anak usaha } \\
\text { syariahnya dalam semua transaksi }\end{array}$ & $\begin{array}{c}2,1 \\
8\end{array}$ & $\begin{array}{c}13,7 \\
5\end{array}$ & $\begin{array}{c}51,2 \\
5\end{array}$ & $\begin{array}{c}28,1 \\
2\end{array}$ & 4,68 \\
\hline 10 & $\begin{array}{l}\text { Saya percaya daya saing bank syariah/unit } \\
\text { usaha syariah rendah jika bersama bank } \\
\text { konvensional }\end{array}$ & $\begin{array}{c}1,8 \\
7\end{array}$ & $\begin{array}{c}29,0 \\
6\end{array}$ & $\begin{array}{c}42,8 \\
1\end{array}$ & $\begin{array}{c}20,9 \\
3\end{array}$ & 5,31 \\
\hline
\end{tabular}

\section{Kesimpulan}

Persepsi kalangan Milenial Bandung terhadap keberadaan dual banking system dalam membuat ketangguhan label perbankan syariah di Indonesia adalah bernilai positif dan dapat dikategorikan sedang. Selanjutnya terdapat pengaruh sebesar 19\% persepsi kalangan Milenial Bandung kepada dual banking system dalam membuat ketangguhan label perbankan syariah di Indonesia. Nilai kekuatan merek perbankan syariah akan mengalami peningkatan sebanyak 0,49\% andaikan terjadi peningkatan persepsi di kalangan sedang terhadap dual banking system. Dengan demikian dapat dikatakan bahwa dampak persepsi kelas Milenial Bandung mengenai keberadaan dual banking system untuk membuat ketangguhan merek perbankan syariah adalah sedikit. Dengan kata lain Fakultas Ekonomi dan Bisnis Islam - UIN Sunan Gunung Djati Bandung 
keberadaan dual banking system dalam membangun ketangguhan merek perbankan syariah di kalangan Milenial Bandung belum berjalan optimal. Meskipun keberadaan dual bankingsystem dalam membentuk kekuatan merek perbankan syariah "Islamic Bank (IB), lebih dari sekedar bank", belum berjalan optimal selama 25 tahun berjalan (1991-2016), namun demikian masyarakat kalangan Milenial Bandung menaruh harapan besar yang berupa keinginan untuk bisa bertransaksi dengan perbankan syariah baik Unit Usaha Syariah (UUS) atau pun Bank Umum Syariah (BUS) di mana pun dan kapan pun. Mengingat keberadaan dual banking system belum berjalan optimal dalam membentuk kekuatan merek perbankan syariah di kalangan milenial Bandung, maka OJK dan perbankan syariah harus lebih agresif dan progresif menjaring jangkauan kalangan milenial Bandung yang tersebar dengan jumlah yang semakin meningkat. Perbankan syariah harus menjalin mitra dengan kalangan milenial Bandung yang umumnya didominasi oleh karyawan swasta, guru, dosen, PNS, karyawan kontrak dan lain-lain dengan jalan menjadi bagian dari kegiatan ekonomi yang dilaksanakan mereka di tempat mereka bekerja dan selalu mudah dibutuhkan di manapun berada. Karena mereka menaruh harapan akan keinginan dan kemudahan mengakses perbankan syariah di mana pun dan kapan pun, maka perbankan syariah harus meningkatkan kualitas dan kuantitas teknologi jaringan informasi teknologi sehingga mampu bersaing dengan bank konvensional dan membawa merek perbankan syariah dengan lambang "Islamic Bank (IB), lebih dari sekedar bank," akan melekat kuat dalam benak masyarakat secara luas.

\section{Daftar Pustaka}

Editor. (2019, September 12). Peran Dan Tantangan Pemuda "Di Era Generasi Millenial" Dipetik 08 Oktober 2020, dari https://pustakabergerak.id/artikel/peran-dan-tantangan-pemuda-di-eragenerasi-millenial

Editor. (2018, September 15). Cermat Pilih Layanan Perbankan Digital ala Generasi Millenial Dipetik Oktober 08, 2020, dari https://www.cnnindonesia.com/ekonomi/20180914193500-83330353/cermat-pilih-layanan perbankan-digital-ala-generasi-millenial

Editor. (2019, September 05). Ekosistem Halal di Bandung Dorong Perkembangan Ekonomi Syariah Dipetik Oktober 08, 2020, dari https://www.pikiran-rakyat.com/ekonomi/pr01318735/ekosistem-halal-di-bandung-dorong-perkembangan-ekonomi-syariah

Mukhlisha Dina Roski. (2019). Dual Banking System di Indonesia dalam Perspektif Politik Hukum Ekonomi Syari'ah. Bandung: Universitas Islam Sunan Gunung Djati Bandung

Alam, Nafis. Efficiency and Risk-Taking. (2012). Dual Banking System: Evidence from Emerging Markets. International review of Business Research Papers

Sutan Remi Sjahdeini. (2014). Perbankan Syariah, Produk-Produk dan Aspek-Aspek Hukumnya, Jakarta: Kencana Prenada Media, Cetakan Kesatu

M.Sadar, Moh.Taufik Makaroi, Habloel Mawardi. (2012). Hukum Perlindungan Konsumen di Indonesia. Jakarta: Akademia

Syukri Iska. (2012). Sistem Perbankan Syariah Di Indonesia dalam Perspektif Fikih Ekonomi, Yogyakarta: Fajar Media Press

Ika Yunia Fausia dan Abdul Kadir. (2015). Prinsip dasar Ekonomi Islam Perspektif Maqasishid alSyari'ah, Jakarta: Kencana

Fakultas Ekonomi dan Bisnis Islam - UIN Sunan Gunung Djati Bandung 
Najwa Aziz Yenny Kornitasari, SE., ME. (2017). Analisis Intermediasi Bank Syariah vs Bank Konvensional Dalam Dual Banking System (Studi Kasus Indonesia), Malang: Universitas Brawijaya

Arna Asna Annisa. (2019). Kopontren dan Ekosistem Halal Value Chain, Salatiga: IAIN Salatiga

Panji Adam Agus Putra. (2017). Kedudukan Sertifikasi Halal Dalam Sistem Hukum Nasional Sebagai Upaya Perlindungan Konsumen Dalam Hukum Islam, Bandung : Universitas Islam Bandung 